\title{
Economic Versus Social Values in Land and Property Management: Two Sides of the Same Coin?
}

\author{
Walter Timo de Vries ${ }^{1}$. Winrich Voß²
}

Received: 1 September 2017 / Accepted: 14 September 2018 / Published online: 25 September 2018

๑) Springer-Verlag GmbH Deutschland, ein Teil von Springer Nature 2018

\begin{abstract}
This article reviews and analyses how and why land-management practice draws on two contrasting value systems: economic and social. Land managers are at the crossroads of different value systems, which both overlap and contrast. The aim of this article is to provide an understanding of which aspects are crucial in each of the value systems, and to provide a basis for how and where the value systems can be connected and where they are contradictory. This is undertaken using an exploratory qualitative and descriptive comparison, which contrasts the epistemic logics of the value systems, the manner in which each system makes use of different scales, and the way in which decisions are made with each value system. Such an understanding is crucial to improve coherence in designing and predicting the future effects of land-management interventions. Currently, practitioners tend to design interventions based on single value systems, rather than on combining or integrating value systems. The discursive comparison provides the initial steps towards a more coherent understanding of the common ground and the missing links in value logics applied in land management. These results are relevant to provide better descriptions and predictions of the effects of land-use interventions and develop improved transdisciplinary models to predict changes and development in the utilization of land or property.
\end{abstract}

Keywords Land management $\cdot$ Contrasting value systems $\cdot$ Tangible values $\cdot$ Intangible values $\cdot$ Economic value $\cdot$ Societal value $\cdot$ Value capture $\cdot$ Market value

Prof. Dr. Walter Timo de Vries

wt.de-vries@tum.de

Prof. Dr. Winrich Voß

voss@gih.uni-hannover.de

1 Lehrstuhl für Bodenordnung und

Landentwicklung, Technische Universität

München, Arcisstraße 21, 80333 München, Germany

2 Geodätisches Institut, Leibniz Universität Hannover, Nienburger Straße 1, 30167 Hannover, Germany 


\section{Ökonomisches versus gesellschaftliches Wertesystem im Land- und Immobilienmanagement: zwei Seiten der gleichen Medaille?}

\section{Zusammenfassung}

Dieser Beitrag untersucht und analysiert, wie und warum für die Praxis des Landmanagements zwei gegensätzliche Wertesysteme von Bedeutung sind: ein wirtschaftliches und ein gesellschaftliches System. Landmanager stehen am Scheideweg dieser Wertesysteme, die sich zum Teil überschneiden und zum Teil kontrastieren. Ziel dieses Beitrags ist es, ein Verständnis dafür zu entwickeln, welche Aspekte in welchen Wertesystemen entscheidend sind, wie und wo die Wertesysteme miteinander verbunden sind und wo sie widersprüchlich sind. Dies geschieht durch einen qualitativen und deskriptiven Vergleich, der die jeweiligen epistemischen Wertesystemlogiken einander gegenüberstellt: die Art und Weise, in der jedes System unterschiedliche Maßstäbe anwendet, und die Art, in der Entscheidungen mit jedem Wertesystem vorbereitet werden. Ein solches Verständnis ist entscheidend, um die Kohärenz bei der Planung und Vorhersage zukünftiger Auswirkungen von Landmanagementmaßnahmen zu verbessern. Derzeit tendieren die Praktiker dazu, Interventionen nach Ein-Werte-Systemen zu beurteilen anstatt Wertesysteme zu kombinieren oder integrieren. Der Vergleich liefert erste Bausteine zu einem kohärenten Verständnis der Gemeinsamkeiten und der fehlenden Glieder in der Wertelogik, die im Landmanagement angewendet wird. Diese Ergebnisse sind relevant, um die Auswirkungen von Landnutzungsinterventionen besser beschreiben und prognostizieren zu können sowie um transdisziplinäre Modelle zu entwickeln, die Veränderungen und Prozesse bei der Nutzung von Boden oder Gebäuden vorhersehen.

Schlüsselwörter Landmanagement - Abweichende Wertesysteme · Quantifizierbare Werte · Nicht-quantifizierbare Werte · Ökonomischer Wert · Gesellschaftlicher Wert · Wertabschöpfung · Marktwert

\section{Positioning of land management}

Since the adoption of the Sustainable Development Goals ${ }^{1}$ it has been possible to note a growing body of literature on how to measure and monitor the degree to which these goals are achieved (Klopp/Petretta 2017; Strezov/Evans/ Evans 2017). A large proportion of the Sustainable Development Goals are land related, as argued by the Global Land Tool Network (GLTN) ${ }^{2}$ and the Land Portal ${ }^{3}$, and as a result, indicators and measurement tools have gained increasing interest in the domain of land management. One of the main tasks of land managers is to deal with conflicting value systems in an appropriate manner. The domain of land management is therefore theoretically and practically challenged: How are indicators part of the use of value assessments and priority settings, which are typical of the field of land management? In other words, the large scientific unknown concerns how to integrate and/or combine different value systems into land-management practice (Raymond/ Bieling/Fagerholm et al. 2016; Teshome/de Graaff/Ritsema et al. 2016).

Furthermore, how is land management actually dealing with combining different indicators and value systems, especially if they are based on different kinds of logics? This paper contributes to answering this question by a compar-

\footnotetext{
${ }^{1}$ https://www.un.org/sustainabledevelopment/sustainabledevelopment-goals/ (19.07.2018).

2 https://gltn.net/home/tag/sdgs/ (19.07.2018).

${ }^{3} \mathrm{https} / / /$ landportal.org/book/sdgs (19.07.2018).
}

ison of cross-disciplinary conceptualizations of values utilized in land management. Land management theories include concepts, methods and models, which are relevant in future spatial development, and a practical applicationoriented element, which is relevant in the procedures of plan implementation. Before being able to combine and integrate different value systems in a comprehensive model and associated management and governance tools, it is first of all crucial to point out which value systems are in use in land management, and how, where and why the utilization of these value systems is currently leading to epistemic knowledge gaps. This article will unpack and compare the different value logics and measurements, and discuss which sort of contradictions and opportunities may arise as a result of the differences.

There is a certain degree of consensus concerning what land management is and which components are part of land management. Land management is considered a domain dealing with the efficient, sustainable and socially acceptable distribution of land rights and land use. Kötter, Berend, Drees et al. (2015: 136) describe it as an "action-oriented component of spatial development and land policy, including all planning and development processes as well as evaluation and regulatory measures for the use of land structural facilities". Magel, Thiel and Espinoza (2016) emphasize the holistic nature of land management, from organizing commitment to changing spatial relations on to executing through all levels of government. De Vries and Chigbu (2017: 66) add that land management can be characterized as a combination of interventions in governance, law, 
socio-spatial relations, economic opportunities, perceptions and behaviour. Finally, Mattsson and Mansberger (2017: 18) remark that although it is impossible to distinguish land management clearly from land administration or land policy and land governance, they refer to land management as "the work related to use of land resources within current policy guidelines taking into consideration the legal framework for a specific land area".

Two examples from different institutional and historical settings illustrate how this complexity relates to conflicting normative values and overriding public interests. First, a recent public TV documentary on a project in Germany shows the effects of conflicts of value systems. It demonstrates the failure of a 30-year-long effort in participation and consensus building aiming to decide between protecting local fauna versus building a highway in a rural region (Bosse 2016). The rationality of a value system based on the financial cost and benefits of developing road infrastructure was incompatible with the rationality of an ecological value system whereby benefits are assessed based on the degree of biodiversity and the likelihood of conserving certain species. There are no fundamental knowledge gaps within the single rationalities, however each lead to different recommendations, and each option has different advocates and adversaries. Second, a recent historical study on land consolidation projects in Poland shows that despite the apparent overall agricultural benefits of consolidating land use and ownership, fragmentation persists because many individual farmers link their identity to their land (Markuszewska 2014). Rationales of agricultural and national benefits in cost savings and profit increases are apparently incompatible with social identity values. Hence, land-use decisions would have to resolve incomparable public and private interests in land use and are thus preventing effective longterm land-use policies at both national and local scales.

In the German context, research has been carried out in the German Federal Ministry of Education and Research (BMBF) program "Research for the reduction of land consumption and for sustainable land management" (REFINA), which produced new strategies to support sustainable development (BMBF 2008). The related theoretical background of these strategies is closely linked to decision theories and algorithms to optimize land use, predominantly relying on economic valuation tools. The implicit (shared) social values in these mechanisms imply that all stakeholders are acting on the same principles as the decision and optimization theories would apply and predict, that all stakeholders are ultimately willing to cooperate and/or reach some degree of consensus on the measures to be taken, and that they can overcome possible contrasting private, organizational and/or political sentiments. However, are these different values at par in both the theoretical assumptions and the practical implementation?
To address this question, this article is structured as follows. First, the two most prominent characteristics of how economic and social value systems are used in land management are explained. Then, the systems are compared through a discursive analysis, taking into account the epistemic logics of the respective value systems, the manner in which each system makes use of different scales, and the way in which decisions are reached with each value system. Finally, we draw a conclusion on how and where the systems could lead to contradictions in land-management goals, conflicts in priority setting in land-management processes or delays in land-management execution.

\section{Economic values in land management}

Values which are based on an economic logic or paradigm are of broad importance for most decisions in land management (Gerber/Hartmann/Hengstermann 2018). Economic values are the main 'language' used in project development between private stakeholders and in cooperation between public and private actors. Even among different public stakeholders - e.g. the national government as the owner of military sites transfers the site of a vacant barrack to the appropriate municipality - the economic value has to be the basis of the transaction price due to budget law.

Economic values are related to a 'market', e.g. the economic value of land is determined in view of the conditions of the land market. Moreover, "markets reflect the attitudes and actions of people in response to social and economic forces and the constraints of law and legal encumbrances" (Appraisal Institute 2008: 2). The concept of economic value is directly linked to the concept of market value. The economic value in the sense of market value represents a whole range of different influencing factors by far exceeding the factors based on economic forces. The concept of economic values furthermore includes social and environmental forces as well as governmental forces (Appraisal Institute 2008: 44). Market value and market forces are linked to governmental controls and regulations (e.g. planning issues, permissions, public infrastructure) which represent 'public interests' and which are linked to the social value system (Appraisal Institute 2008: 31).

The different contents and functions of economic values in land management are demonstrated in the following examples with regard to different land-management applications. Starting with a focus on pure market values including sustainability factors (Section 2.1), attention then turns to the increase in contents and functions with cases of full compensation in expropriation procedures (Section 2.2), before going on to land value increase and value capturing in modern private-public land development projects (Section 2.3) and the approach of cost-effectiveness analysis 
including intangible indicators in land consolidation procedures (Section 2.4).

\subsection{Ground rent theory and market value}

According to neo-classical "ground rent theory" the economic value of a location or place is strongly related to the conditions of land use and production, especially in view of competitive land uses and most transparent market information (Jowsey 2011: 30). The logic of neo-classical value theory is that the economic value of an (agricultural) location is derived from the return of the best land use represented by the highest land rent (Smith 2005). The return - and economic value - is determined by locationbased characteristics (location factors such as accessibility and centrality). The model includes a relation to the costs and presumes that the return minimum covers the costs (e.g. production, manpower, transportation to market). Otherwise the land use would not take place.

The theory of property valuation states that the current market value represents the 'value' of a plot. Market value today is defined in this way in countries with market economy systems. The International Valuation Standards Committee (IVSC) defines market value as "the estimated amount for which an asset or liability should exchange on the valuation date between a willing buyer and a willing seller in an arm's length transaction, after proper marketing and where the parties had each acted knowledgeably, prudently and without compulsion" (RICS 2017: 10). While the specific 'price' paid includes - alongside current competition on the market - all circumstances relevant for an individual buyer or seller, the 'market value' (only) includes the circumstances relevant for a majority of buyers and sellers.

The market value is influenced by a conglomerate of factors. These factors are of very differing character and background (economic, legal, technical, social, ecological, mental, historical, psychological) but the market value arises as the sum of the economic consequences of these different factors. The value of a property is determined by prices paid in realized transactions of comparable estates (comparison approach). It is also possible to use approaches based on specific parameters. The comparison is limited to the most important parameters, e.g. the return in case of rented properties (income approach) or the costs of construction (cost approach).

Important factors for market values are aspects legally fixed in the public/societal interest, e.g. the land use designated in public plans or planning permits, or restrictions such as social housing quotas or monument protection. Location-based factors are another very important group, including accessibility, quality and image of neighbourhood, and infrastructure. Also of relevance are many societal as- pects in nearby locations like - in the case of residential locations - public greens or social and cultural infrastructures (e.g. health-care facilities, schools/education institutions or famous places and monuments like cathedrals or museums; Appraisal Institute 2008: 66). The market value of private properties in each location includes the economic impact of public and societal facilities on private property holdings.

Finally, it is interesting to have a look at the market value of public infrastructure itself, like a public green in a residential neighbourhood or a park near the city centre. The theory of property valuation allocates no market value for such land as long as the land use remains 'public' and property ownership is limited to one party without competitor, here the municipality (Kleiber 2017: 2438). If the municipality develops a new public green, land acquisition might be necessary. In this case, it is not the future land use that is crucial for the price to be paid, but the value of land according to former land use. The valuation complies with the rules of compensation in case of an alternative expropriation. If a private developer plans a new neighbourhood (residential or commercial) including public greens, roads etc., the value of the public green plot - like the value of the land for roads - is not differentiated and is automatically incorporated in the whole development calculation (see Section 2.3). The economic value is represented by the costs of the infrastructure. It is an issue of financing and of skilled management by the developer.

Mooya (2016) looks critically at the recent theory of real estate valuation. He shows that the standard theory based on the neo-classical approach is appropriate for highly competitive markets only, e.g. the market for family homes or commercial properties in the United Kingdom. There is a "theoretical continuum of market types, with 'no market' at one end and the perfect competitive market at the other" (Mooya 2016: 128); the latter is compared to the functioning of the stock market. Transaction activity is the decisive indicator. The thin and absent property markets have different frameworks and are in need of an alternative valuation approach (Mooya 2016).

These theoretical aspects confirm that the concept of market value as an economic value requires differentiation. On the one hand, the paradigm of market value includes many aspects related to the public and societal framework as far as they influence the viable land use and image of a location. On the other hand, the economic value in thin or absent sub-markets, e.g. the aforementioned market of infrastructure projects/plots or property types or locations with rare transactions, could be derived in relation to the invested costs. Another category is the value of public goods such as clean air or water or healthy food. These intangible indicators are not incorporated directly in market values and are investigated in Section 3.3. 


\subsection{Expropriation and compensation}

The market value paradigm is strongly anchored by the philosophy of private ownership rights and their compensation in cases of compulsory purchase. The loss of property ownership rights has to be compensated by market value. If the loss of property rights causes further disadvantages (e.g. damages to the remaining part of the plot or to the expropriated party, e. g. cost of moving or extra expense to re-start a business in a new location), these consequential damages have to be additionally compensated. The legal basis and aim of compensation demands an amount which enables the expropriated party to buy a new property of the same quality, usability and sentimental 'values' with respect to the market conditions at the date of loss of ownership (Voß 2010; Aust/Jacobs/Pasternak 2014). If - in consequence of this idea - the remaining part of the property benefits, e.g. from new road accessibility, the profit in land value is calculated against the compensation.

The 'emotional' or 'subjective' aspects of a specific plot ownership, e.g. traditional family ownership according to the location, being a member of the neighbourhood or mental impacts of the property or landscape, are not part of the compensation or consequential damages, although they might be of strong importance for the former owner. Market value as an economic value does not cover these subjective aspects of values.

One of the first countries to offer a margin of this sort in the compensation standards is Sweden. Today the expropriation law in Sweden requires compensation according to current market value plus a surcharge of 25\% (Kalbro/ Paulsson 2014: 229). The surcharge is motivated by shrinking the (normal) gap between the property owner's reservation price and the market value. The owner's reservation price is the minimum price the seller demands to sell the property within a voluntary agreement (Kalbro/Paulsson 2014). The surcharge bridges the gap between the market value and the full equivalent of the expropriated assets and might cover part of the subjective and emotional value. The flat surcharge may also cover uncertainties in market value estimations. Compensation related to consequential damages like moving costs is also granted additionally in Sweden.

\subsection{Value capture in urban land development procedures}

Due to the necessity of coordinating land use by public authorities, since the introduction of modern planning systems in the form of an important legal framework of spatial development and land and property markets, the economic value of land is determined by the best land use (Appraisal Institute 2008). Economic value emerges in strong correlation to planning permission and the underlying land-use planning. In countries with legally binding development plans, e.g. Germany, the economic value of developed land is already anticipated during the official procedure of plan preparation, while in countries with non-binding development plans, e.g. the United Kingdom, the approval of planning permission is causal for the impact of planning on land values (Voß/Dransfeld/Dieterich 1994). Furthermore, the public interpretation of planning policy and statements by local authorities is important too. In this sense even informal planning activities may influence economic values in a modern planning system.

Each step of planning that attracts public attention may have an impact on the economic value of a location. In the German philosophy of land development, the price-setting process follows the planning and implementing activities of
Figure 1 'Stairs model' of land development according to the German planning system. Source: Voß/Dransfeld/ Dieterich (1994: 201), based on Ernst/Bonczek (1971: 76) and Seele (1976: $63 \mathrm{ff}$.), adapted

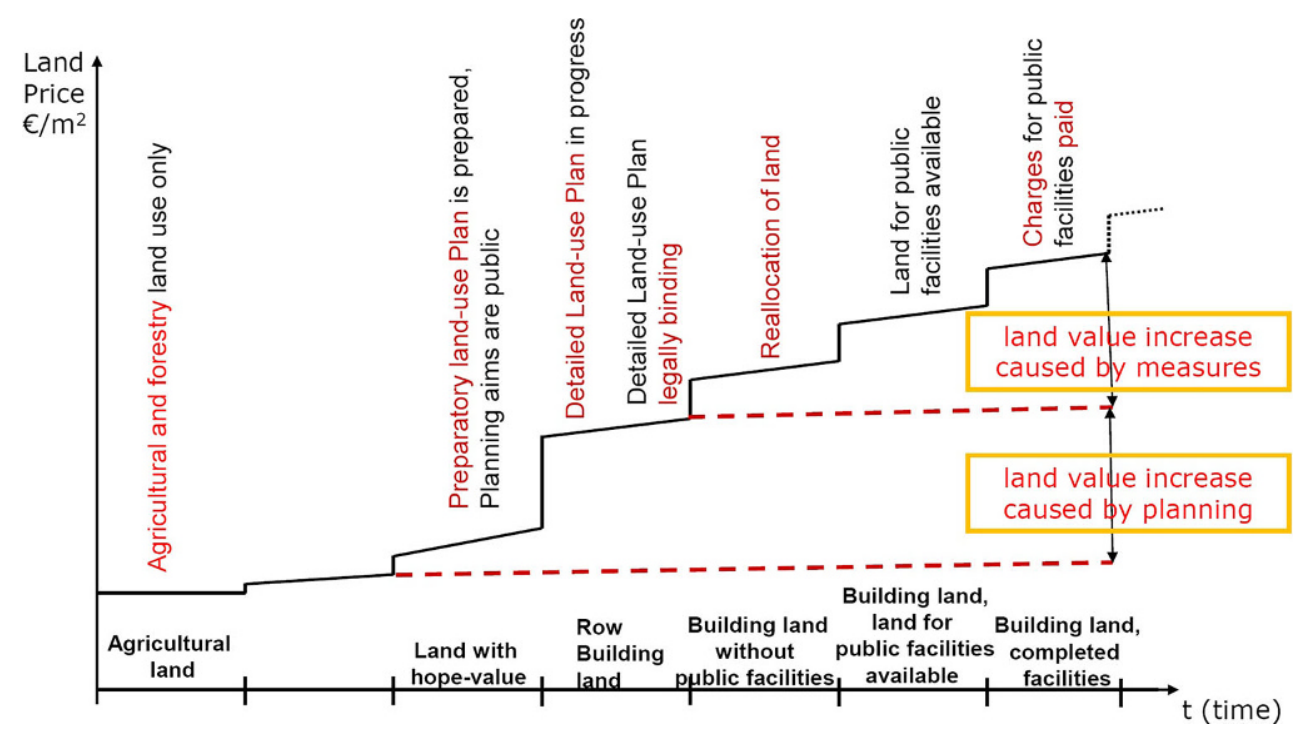


the municipalities as illustrated by the 'stairs model' (see Figure 1).

In the development process in Germany land value increase is predominantly provoked by public planning and implementation measures (plot reallocation, public facilities). This is the reason that municipalities have the power to participate in capturing development gains with the help of co-operative strategies based on urban development contracts. The advanced models used today are called Baulandmodelle (building land models) and combine ecological (e.g. energy-saving premises), social (e.g. promoting affordable housing) and financial (e.g. full cost coverage) public goals in co-operative implementation strategies (Drixler/ Friesecke/Kötter et al. 2014; Voß 2014). Public goals are transferred into economic values, relations of costs and value potentials are addressed in advanced land-management tools. A crucial part of the tool is the development calculation.

An urban development calculation is a project development tool which relates the resources invested in a project to the outcome. The overall result can be a 'project yield', an important type of economic value in land management. Such tools are regularly used by private developers, and increasingly by local authorities - in the position of public developers or in public-private co-operations. In the simple version, the tool gives information about the economic efficiency of a project, including land resources, development costs, time schedules, financing issues etc., in relation to returns in terms of selling prices or rent income (Kötter/ Frielinghaus 2012).

In an advanced version, the method offers the possibility of including all resources relevant in a sustainable development approach. Depending on the range of resources input (e.g. including ecological or 'public' resources), different types of yields may be calculated (e.g. urban yield, sustainable yield) - as far as appropriate models and data are available. As well, public/societal resources could be included if the data are rendered manageable. The tool is very helpful in comparing different solutions of a project idea and evaluating the impact of planning variations. It supports negotiations between municipalities and developers/investors when arranging public-private co-operation in urban development.

\subsection{Cost-effectiveness analysis in land consolidation procedures}

Land consolidation procedures are public land management projects aiming for improvements in rural living and working conditions as well as the structural development of rural areas. They are also able to implement big public infrastructure projects. Rural development by land consolidation in Germany is a responsibility of the federal states.
They regularly claim for a cost-effectiveness analysis before a new land consolidation procedure is started and the budget is approved (e.g. North Rhine-Westphalia, Lower Saxony, Rhineland-Palatinate, Bavaria).

According to the Federal Land Consolidation Act $^{4}$ the intention is to serve private land owners/farmers (improving production and working conditions in agriculture), and also to safeguard public resources and improve development opportunities to increase the public wealth of rural areas. The specifications of the cost domain in the analysis are calculated using standard benchmarks derived from experiences of former projects. The effectiveness indicators are derived from a cascade of aims and sub-aims. These indicators may be both tangible and intangible. The impacts are determined in four areas with 35 indicators, of which about $50 \%$ are classified as intangible (Forschungsgruppe ART 2008: 10). The selected examples in the following are classified as tangible indicators:

- Farm-related indicators (e.g. savings in machine costs, savings in work time in managing a farm),

- Social and agro-structural indicators (e.g. number of new workplaces for family members or external workforce, saved work time for recreation or family support, improved workplace security),

- Ecological indicators (e.g. reduction of water pollution, reduction of flood risks, reductions in carbon dioxide emissions from farming),

- Regional economic indicators (e.g. improved traffic infrastructure, improved quality of landscape for recreation and leisure time, support for municipal developments).

Examples of intangible indicators are, e.g., reducing land-use conflicts and establishing legal certainty, improving transparency on the land and rental market, improved contentedness in agricultural business, safeguarding ecological habitats or the improvement of co-operation between municipalities. If specific additional aims are important in a region the list of indicators should be flexible. In Rhineland-Palatinate the cost-effectiveness analysis was extended to include wine-growing districts and forest land consolidation (Hinz 2012).

Evaluation systems like the cost-effectiveness analysis are important exercises to improve land management value systems. The tool has been in continuous use for about a decade. Many of the land consolidation projects prepared with a prior cost-effectiveness analysis are not yet complete. Evaluations and improvements will be possible in the coming years when proposed effectiveness can be compared with reality. This will be a good opportunity to compare and gain experience of the different value logics which are included in the tool.

\footnotetext{
${ }^{4}$ Flurbereinigungsgesetz (FlurbG).
} 


\section{Social values in land management}

\subsection{Type of logic in social value systems}

Recent discussion about the use of indicators of rural development and spatial injustice (Magel 2016; de Vries 2017a) have triggered a debate on whether more quantitative values related to property management and investment could effectively be compared and/or integrated with more qualitative values associated with strategic spatial development, changes in society, calls for ecological protection and new forms of governance. In this article, we refer to 'social' values when these are generated, legitimated and/or institutionalized through social interactions. Social value systems are then sets of values which guide social behaviour and which provide agreed sets of frames for social actions. One could also call these values 'public' values, emphasizing their common or public nature, or 'societal' values, emphasizing the fact that they guide interactions within a society or societal system. However, in this article we prefer the term 'social' as the values we refer to have both a social origin and a social implication. When speaking about social values one does not speak directly of factors which are absolute or which can be measured or indicated in absolute and very generic forms. Instead, social values are by nature subjective, as they may relate to particular social interactions. As a consequence, the logic guiding the formation and application is fundamentally bounded rationality, as it may change according to new perceptions and new priorities which arise through social interaction.

Social values are fundamentally opposed to economic logics which are considered fundamentally predictable, measurable and objective. Social values deal, on the one hand, with what individuals, participants, neighbours, communities, stakeholders, crowds, advocacy groups and political factions find relevant, important, significant or imperative, and, on the other hand, with what public service systems (either in the form of public administrations and/or in the form of constellations of public and private organizations working on public tasks) consider possible and feasible in the execution of a public service. Often, such values are highly dynamic and rather fluid and, most importantly, they rely on interactions and reactions between the various types of subjects. Simply put, what an actor 'values' as relevant and important here and today may differ from what that same actor 'values' as relevant and important somewhere else and tomorrow. In other words, social values are socially and politically shaped and constructed. They highly depend on time, location, context and framing.

Nevertheless, Moore (1994) is one of the first who argued that there is a need to define social value in such a way that it becomes measurable and workable for public managers. $\mathrm{He}$ defines public social value as an intangible good produced for citizens and other stakeholders, whereas private value primarily derives from private value created by and for economic actors. The need to define and measure is to support managers to achieve mandated purposes as efficiently and effectively as possible, to support the development of analytical techniques to capture social value, and to provide for measuring the satisfaction of stakeholders. Cook and Harrison (2015) argue, therefore, that it is not the shape, content or construction of values that are important, but the impacts which an intervention may have. Hence, values are determined by the results of public actions. The impacts of public social value can be socio-economic, related to quality of life, political or ideological. Hence, the way that interventions change issues such as community relationships, social mobility, future income, household security, political opportunities, moral beliefs and commitments is a manifestation of social values in action.

\subsection{Types and units of social values}

In general, one can identify a number of social values which play a role in land management science and practice. Given that land management has a public function, the public value categorizations of Kernaghan (2003) and of Bannister and Connolly (2014) are relevant for understanding how social values are manifested. Kernaghan (2003) distinguishes public values in four categories: ethical, democratic, professional and people. Table 1 displays how these are identified.

Similarly, Bannister and Connolly (2014) classify values which need to be upheld by public administrations into three categories: duty oriented, service oriented and socially oriented (see Table 2).

It is obviously possible to find and present many such categorical overviews of how and where social values with a public character play a role, but the two lists presented above suffice - especially as there is a reasonable degree of overlap between most of these lists, although names or qualifications may vary. What is important, however, is for whom these values play a role and how they are specific to the domain of land management.

\subsection{Creators and users of social values in land management}

In general, social values can be categorized along four categories of actors who create and act on the values: individuals, epistemic communities, public service orientations, crowds. Each resulting type of values can be further explained.

Individual stakeholder oriented values consist of classifications, frames, priorities, beliefs, and perceptions of individual actors. There is great variety in the themes in 
Table 1 Categories of public values

\begin{tabular}{llll}
\hline Ethical & Democratic & Professional & People \\
\hline Integrity & Rule of law & Effectiveness & Caring \\
Fairness & Neutrality & Efficiency & Fairness \\
Accountability & Accountability & Service & Tolerance \\
Loyalty & Loyalty & Leadership & Decency \\
Excellence & Openness & Excellence & Compassion \\
Respect & Responsiveness & Innovation & Courage \\
Honesty & Representativeness & Quality & Benevolence \\
Probity & Legality & Creativity & Humanity \\
\hline
\end{tabular}

Source: Kernaghan (2003: 712), own illustration

Table 2 Taxonomy of public values according to Bannister and Connolly

\begin{tabular}{lll}
\hline Duty oriented & Service oriented & Socially oriented \\
\hline Responsibility to the citizen & Service to the citizen in his or her different & Inclusiveness \\
$\begin{array}{l}\text { Responsibility to the elected politicians of the } \\
\text { day }\end{array}$ & $\begin{array}{l}\text { roles } \\
\text { Respect for the individual }\end{array}$ & Justice \\
$\begin{array}{l}\text { Proper use of public funds } \\
\text { Compliance with the law }\end{array}$ & Fesponsiveness & Equality of treatment and access \\
Efficient use of public funds & Effectiveness & Respect for the citizen \\
Integrity and honesty & Efficiency & Due process \\
Facilitating the democratic will & Transparency & Protecting citizen privacy \\
Accountability to government & & Protecting citizens from exploitation \\
Economic/parsimony & & Protecting citizen security \\
Rectitude & & Accountability to the public \\
& & Consulting the citizen \\
\hline
\end{tabular}

Source: Bannister/Connolly (2014: 123), own illustration

Table 3 Examples of social value types

\begin{tabular}{ll}
\hline Value types & Examples of value systems \\
\hline Individual stakeholder oriented & Tenure security, safety, right to the city/right to village life, Stability in neighbourhood, quality of life \\
Epistemic community oriented & Socio-cultural opportunities, social cohesion indicators, type of boundary conflicts \\
Public administration and public & $\begin{array}{l}\text { Social equity, economic equality, equal access to services, access to and functionality of technical infras- } \\
\text { service oriented }\end{array}$ \\
tructure & Public interests, convenience of public services, equity in access to opportunities, spatial identity \\
\hline
\end{tabular}

which an individual stakeholder is interested, but usually these values apply to a relatively limited geospatial scale or even a particular location. Examples are individual farmers who may express the need to work close to their homestead, not because of economic reasons but motivated by community identification. Closeness, community is in this case a qualitative value.

Epistemic community oriented values refer to groups of individual actors who hold similar values and act using those values in similar ways. Examples include farmers' associations, technical or legal professionals with similar educational backgrounds, or political advocacy groups. They maintain certain practices and beliefs which are historically based and are therefore seen and maintained as just or valid. A cadastral surveyor conducts cadastral surveys according to a particular practice, not only because this may be prescribed as such but also because alternative types of cadastral measurement (which might lead to results of similar quality) are excluded from being acceptable within this epistemic community. Loyalty, cohesion and stability are in this case prominent values.

The category of public service oriented and public administration refers to organizational entities entrusted with public service tasks. They can either be specific public organizations, such as ministries, regional government or a municipality, or semi-public or quasi-public organizations, such as state-based enterprises (e.g. railway companies, financially autonomous cadastres) and/or quasi-public corporations and public service corporations (e.g. social housing, electricity providers). Responsibility, accountability, neutrality, uniformity and responsiveness are crucial values here. They result from 'seeing like a State'.

Crowd oriented values refer to collections or combinations of multiple types of stakeholders who pursue a particular interest and shape values by advocacy and by collecting and presenting data in a particular manner allowing multiple values to emerge. Often these are loose interests groups, especially supported by social media, or more orga- 
nized groups such as non-governmental organizations. This distinction leads to the following set of values and value systems relevant for land management (see Table 3).

\subsection{Examples of social values in land management}

For illustrative purposes four types of social values are further discussed: land tenure security, quality of life, right to the city/right to village life, spatial identity.

Firstly, the discourse of tenure security often refers to land and property institutions in developing countries. It is a basic concept for most countries where land or property ownership, use, access, or transfer cannot be guaranteed by the State or by a local community. Land tenure becomes insecure if possibilities exist for expropriation, eviction and land grabbing, amongst others. Dushimyiman Simbizi (2016) shows that tenure security is a measurable value, which depends not only on the fairness and efficiency of public legislation, but also on social and customary institutions and the continuum of land rights. This implies that the broader framework of tenure security provides a logic other than that of economic rationality. This implies that tenure security is also an issue in developed countries. A simple example shows this: in economic logic, tenure security is directly coupled to payments of rent or mortgage, or to compensation. One becomes insecure if one's financial means become restricted. The financial crisis in 2008 showed this direct connection. By contrast, the logic of the continuum of land rights and that of social institutions sees tenure security as coupled to social acceptance. One becomes tenure insecure if the community starts to limit access. The variations in tenure security are therefore best represented as a large continuum with multiple on and off switches of rationalities.

Secondly, quality of life is an important objective of many (spatial) planning theories and projects, and consequently plays a crucial role in land management. However, it is at the same time a highly disputed and extremely complex and multifaceted concept, as it relates to physical, spatial and socio-economic characteristics.

Thirdly, the 'right to the city' (and associated 'right to village life') has been derived from critical urban theory. Introduced by Lefebvre (1996), it does not refer to a formal right in spatial legislation, but multiple authors have used this concept to link tenure security to urban livelihoods, urban space and tenure rights and to the formalization of tenure rights in (peri-)urban areas (e.g. Mitchell 2003). The concept confronts economic rationalities in managing land and properties by arguing that optimization of economic returns and profits should not be the basis for spatial development (Brenner/Marcuse/Mayer 2012), which should instead be based on providing high-quality and highly accessible public services. Many of these discussions go back to the theory of territorial justice and the right to govern land and property (Boyne/Powell 1991; Miller 2012).

Fourthly, a value which is considered especially relevant in discussions about rural development is that of spatial (rural) identity, particularly when this concept is connected to the strategy of spatial/regional branding (Kalandides 2011). Branding optimizes the socio-economic potential arising from the unique characteristics of a local area or place. Such an optimization strategy assumes, however, a basic set of values (including null-values) with which spatial identity can be measured and compared.

\subsection{Data collection and presentation methods of social values}

There is still little knowledge or experience on how to collect, measure and present social values most effectively and appropriately. One of the dilemmas hereby is that an important characteristic of information on social values is that it is not 'value-neutral'. Experience has shown that maps showing socio-cultural and socio-economic differences usually trigger political and ideological reactions, and reversely that maps tend to be used to stress or omit a 'hot' political issue (de Vries 2008; Moody 2010).

Fortunately, both legal-institutional and technical instruments are available to support land-use decisions. Various EU directives (e.g. the Habitat and Birds Directives) provide guidelines for applying certain normative value systems. With currently available data (supported by the EU's INSPIRE Directive, for example) and increasing possibilities for interconnecting different types of hardware tools, it is now possible to address more complex data-driven decision-making methods. This requires, however, reconciliation of different disciplinary rationales, logics and objectives. By forging connections between distinct units of analysis, a better understanding can be achieved of causeeffect relations and the possible impacts of given decisions. The State has an active role in this model in Germany, both as an enabler and a facilitator in ensuring spatial justice, for example. The implication is that the State has also developed a particular means by which this social value must be measured. The spatial information tools and models that support the State in providing spatial justice include nationwide indicators on access to public services, nationwide datasets on cultural landscapes and vitality checks of local villages, for example. Hard data (on soil, topography, socio-economic indicators, long-term vacant land or buildings) are combined with soft data (e.g. on social preferences and cultural landscapes). 


\section{Discussion: The common ground and missing links}

When comparing and aligning the different value logics, it is necessary to consider how to align the epistemic logic of different value systems, how to make use of and benefit from existing variations in utilizing value systems at different scales, and the manner in which decisions are prepared and executed.

\subsection{Aligning the epistemic logics of different value systems}

One of the missing links when comparing the epistemology of economic and social values concerns how each of the value systems gains meaning in the other value system. Value has meaning to stakeholders in the manner in which actors engage with the manifestation of the values (de Vries/ Miscione 2010), which is usually in the form in which social contracts emerge as a result of the social interactions. Economic values gain meaning through a basic assumption that one can predict and measure the (financial) effects of choices in (economic) transactions. Essentially, they have to be because there needs to be a connection to the expected expenses. This justification is by definition a manifestation of a certain degree of objectivity towards future developments. Professional actors rely on such objective models for their decisions, and also act upon these models even though some of the benefits may be qualified as intangible (yet expectable). The property market and professional property developers typically rely on such economic value systems. They will strive for those economic choices which prove to be profitable for those who invest, for example (not necessarily for those who benefit). In contrast, social values are much more intangible and qualitative. There are higher margins of error assumed, and acting upon the values is much more based on shared acceptability and a shared idea of rightfulness.

One could, however, also argue that there exists a certain epistemic continuum of values, which is connected through the common ground of optimization - as both economic and social value systems tend to favour some sort of optimal state. This state is reached through favouring behaviour which reinforces certain shared values and disfavouring actions which contradict the main logic of the respective value systems. Table 4 illustrates the continuum of values and objectives pursued by each of the relevant disciplines. Whereas real estate and agricultural economic value systems primarily reason from quantitative logic and certain degrees of predictability, human geodesy and landuse planning use logic based rather on social acceptability, legitimacy of actions and certain unpredictability. However, in the manner of optimization one may equally reverse the logics.

In the field of land management this concerns the making of a land-use plan or a land-use assessment, for example. Currently, integrating value systems using different logics requires an extensive blending of disciplines along with a re-formulation of optimization measures. If each discipline keeps on advocating its own models as the most relevant, the resulting scenarios, predictions and recommendations for land-use interventions may remain difficult to reconcile and might even be mutually contradictory. However, if logics are combined in such a way that social scenarios and interactions are respected, one may reach a certain degree of reconciliation of value logics.

One manner to integration and reconcile values is reasoning from the existence and need for (socio-spatial) boundary objects. Boundary objects have both a physical and a social connotation. On the one hand, boundaries are locations where spatial characteristics, values and objects undergo fundamental changes with economic impacts (e.g.

Table 4 The epistemic continuum of land management values

\begin{tabular}{|c|c|c|}
\hline Scientific/professional discipline & Units of interaction & Optimization logics \\
\hline $\begin{array}{l}\text { Real-estate economics (Squires/Heurkens } \\
\text { 2016) }\end{array}$ & $\begin{array}{l}\text { Land and property market; land price; specu- } \\
\text { lation; change of land use and ownership }\end{array}$ & $\begin{array}{l}\text { Land value; market value; profit margins/ } \\
\text { profit potential; cost savings; cost benefits }\end{array}$ \\
\hline $\begin{array}{l}\text { Agricultural economics (Schmitz/van Meijl/ } \\
\text { Kyle et al. 2014) }\end{array}$ & $\begin{array}{l}\text { Soil type and (potential) use; variety and } \\
\text { potential of crops; parcel size }\end{array}$ & Yields; diversification potential \\
\hline Rural development (Chigbu 2012) & $\begin{array}{l}\text { Changing rural landscapes; socio-economic } \\
\text { opportunities; socio-spatial identity }\end{array}$ & $\begin{array}{l}\text { Socio-economic equality between rural and } \\
\text { urban areas; rural vitality; impact values }\end{array}$ \\
\hline $\begin{array}{l}\text { Territorial ecology (Veldkamp/Polman/ } \\
\text { Reinhard et al. 2011) }\end{array}$ & $\begin{array}{l}\text { Dynamic variables of soil, land use, water } \\
\text { (use, quality) }\end{array}$ & Ecological value; preservation; metabolism \\
\hline Human geodesy (de Vries 2017b) & $\begin{array}{l}\text { Parcel rights; fragmentation of land owner- } \\
\text { ship and use }\end{array}$ & $\begin{array}{l}\text { Human-attentive division of land ownership } \\
\text { and allocation of land use }\end{array}$ \\
\hline $\begin{array}{l}\text { Spatial planning and land law/legislation } \\
\text { (Ali/Deininger/Goldstein 2014) }\end{array}$ & $\begin{array}{l}\text { Legitimate and legal land rights and land use; } \\
\text { land regulations; access to land rights }\end{array}$ & $\begin{array}{l}\text { Tenure/rights security; equal access to land } \\
\text { rights; implementability of new policies } \\
\text { within the legal context }\end{array}$ \\
\hline $\begin{array}{l}\text { Land-use planning and development (Perin } \\
\text { 2014) }\end{array}$ & $\begin{array}{l}\text { Land-use types or units; land-use zones; } \\
\text { land-use restrictions }\end{array}$ & Social acceptability; resilience; (urban) yields \\
\hline
\end{tabular}


legal boundaries of ownership or land tenure between two land parcels, boundaries of land use and related economic value boundaries between urban, peri-urban and rural areas). On the other hand, boundaries are also abstract notions reflecting different leitmotivs, opinions or beliefs, expressed through disciplinary or professional perceptions of epistemology and ontology (contrasting governance positions, policy beliefs or gradually adopted social perceptions). For this reason, many land-use analyses based on contrasting ontologies result in different policy recommendations. Such a situation is most obvious close to the administrative boundaries of local governments, each of which implement a different local land-use policy. The boundary object theory, originally developed by Star and Griesemer (1989), is relevant in this context. Once different land-use stakeholders start to collaborate in the design of future land policy and land-use objectives, they will have to find a common transdisciplinary 'language' of value models, acceptable and recognizable to all. This is not just a matter of choice between economic or social values and models but also involves creating a new system of values and models. These enable the stakeholders to transcend their former perceptions and reach new and consensual solutions.

As indicated in Section 3.5, epistemic differences have an effect on data, data standards and data models as well. The emergence of big and linked data could, however, implicitly foster a certain degree of reconciliation of these spatial data differences. Compared to small data, big data are supposed to be highly flexible and scalable and strongly inter-relational. Practically this implies that the analytics embedded in big data technologies (algorithms and supporting software) are geared to generate plausible links and patterns between completely different types of data sets, and thus also foster new ways of looking at the single data sets. Again, this is not a value neutral activity, as the norms are hidden in the algorithms behind the technology. Therefore, it remains pertinent to keep a close eye and reflect regularly on how which values are carried forward by new technologies.

\subsection{Spatial scales of value systems}

A missing link between the economic and social values certainly constitutes the use of different institutional administrative boundaries for various types of land management applications. These tend to be derived partly from the spatial units at which epistemic values are shaped (i.e. administrative regions for rural development tend to relate to the manner in which the goals of rural development are perceived; the administrative regions of property insurance companies tend to be defined differently).

Moreover, a possible connection between different value systems can be made by detailing the use of value at differ- ent scales. Application-oriented land management is relevant at different planning and administrative levels. At the regional level, land management supports social values such as 'Equivalent living conditions' principles (gleichwertige Lebensbedingungen; one of the key aims of German regional policy) through the economic value logic of developing the most optimal urban-rural accessibility structures based on areas of commuting distances. An important field of land management activities is the implementation of strategies to reduce land consumption at regional and at local level.

At the local level, the simultaneous utilization of different value systems for the implementation of land-use interventions becomes most concrete. Local land managers are responsible for the development of viable locations to live and work, summarized in the 'quality' of an urban district, a village, a neighbourhood or - in general - a location. This is reflected in the social value of a location and, finally, in the economic/market values of properties. Similarly, the implementation of inner-urban development strategies prior to new greenfield developments is a current central task of land management. At the level of neighbourhoods/villages land management is necessary if a project covers a number of plots in different ownership or if a project creates infrastructural demands in the neighbourhood.

Two aspects are very characteristic for the land management topic. Firstly, land management always takes place in the sphere of convergence of public and private interests represented by public and private stakeholders. In general, the balance between private and public powers is fixed in laws (e.g. constitution, property law and building law) and becomes concrete in legal tools (pre-emption rights, re-allocation rights, and expropriation rights). In specific development projects, the balance finally is created by the negotiation of private and public stakeholders. In these cooperative approaches it would be helpful to 'translate' public aims/values into economic value logics.

Secondly, in land-management procedures evaluations and values are essential and indispensable. They are necessary to judge the advantages and disadvantages of parties in relation to the municipality or third parties, to create win-win-situations. Valuations and values are at the centre of land management and they are an essential part of 'the heart of land management'. The distinction between types of values remains one of the main challenges in both land management theory and practice, as it is necessary to align and accommodate these different types of value logics when preparing and executing land-management interventions. Examples include the a priori assessment of most optimal spatial scenarios which requires a combination of values based on costs (economic values), environmental indicators (ecological values) or societal choices and preferences (societal values). These values are important for 
the calculation and payment of compensation (in cases of eviction or expropriation), for seeking comparative ecological replacement areas (in cases where the intervention has negative externalities for the ecology), or for seeking livelihood alternatives (in cases of fundamental socio-spatial disruptions in daily life and social activities). The underlying logics of these respective value systems, and the associated proxies necessary to measure or qualify them, differ significantly. As a result, it remains difficult to combine these into one system of measurement, with a single unit and single manner of assessment.

\subsection{Supporting decision making and monitoring by values in land management}

Land management and its value logic is not limited to direct plan implementation as shown in the examples above, but can additionally contribute to decision making and evaluation of development projects in urban or rural areas (supporting decision making with land management tools). The aim and task of land management involves offering realistic solutions for the implementation of urban or rural development projects. If alternative solutions are available, the 'best solution' within the frameworks of planning, location and involved stakeholders should be selected. In these cases land management supports the decision-making process by providing comprehensive indicators or values. This is furthermore necessary if running projects have to be evaluated or in cases of recurrent monitoring. The combination of public/societal and economic values is of great importance in decision support because the public aims are often put forward.

In decision support and performance monitoring matters, results which provide values in absolute terms, e.g. in euros, are unhelpful. Decision support requires the correlation and comparison of project aims - or the aims of a strategy or a plan/planning - and the expected results or impacts of the project. Economic values are likewise important aims, but they are in correlation or opposition to many other factors. In rural and urban development projects these aims are partly tangible and partly intangible. However, even the tangible aims often cannot be evaluated in economic units, e.g. number of low-carbon premises, proportion of social housing units, changing modal split with priority to bicycles or public transport, improving air quality by green spaces. Due to some aspects, valuations are set up by comparing proportions of the situation within the new development area to the average of the district or the whole town; data availability is one of the challenges here. More difficult is the categorizing of ecological aims, e.g. to prevent urban sprawl and land consumption by prioritizing inner-urban development. Here relations according to national or international benchmarks could be helpful (BMBF 2008). Ultimately, the final challenge is to weight, balance and merge the different categories of 'values' or indicators to an overall result.

In general, decision support tools have been part of research for decades. In practice, these experiences are mainly available due to planning decisions, especially in cases of ranking planning alternatives, e.g. routing alternatives for new roads or high voltage power lines, or location alternatives for wind farms, repositories, power stations or retail centres. In the field of land management as the implementation strategy in urban and rural development, project decision-support tools are still rare. The examples of urban development calculation and cost-impact analysis in rural land consolidation demonstrate some ideas for combining the different logics but challenges remain, particularly in the availability of data and weighing-up the different aspects.

\section{Conclusion}

Returning to the key quandary, i.e. how to overcome inter-disciplinary differences in conceptualizations of values, we evaluated examples and logics of two main value systems - economic values on the one hand and social values on the other hand. The discursive comparison provides the first steps towards a more coherent understanding of the common ground and the missing links in the value logics applied in land management. The missing links can be found in the epistemic differences between the multiple fields which are relevant in land management, which currently still prevent further convergence or integration of values. This common ground may be found in a number of converging boundary objects, which are stimulated by several policy and technical developments at European level, and by the execution of day-to-day land management decisions at regional and local levels. Practically speaking, the further development of decision-support and planning-support systems can help to converge different value system logics.

Given these findings, we note that there are still a number of contradictory goals in the value systems applied in land management which hamper the success of land-management interventions. First of all, the spatial units at which values are socially constructed may lead to institutional conflicts. Often administrative boundaries reflect a fundamental preference for a monolithic value system. Managing land through different institutional frameworks is likely to increase contradictions and disputes. Similarly, managing land through monolithic institutional frameworks is likely to increase contradictory outcomes. Hence, there is a fundamental need for a continuum of epistemic value systems, whereby the basic notions of each of the respective systems can be continuously challenged by any of the other systems. Through this more dynamic application of value 
systems, where none of the systems is preferred over any of the others, but each of the systems can be applied wherever and whenever considered appropriate and legitimate, it may be possible to reach a fit-for-purpose value system for each land management problem.

In view of the requirements of a transdisciplinary approach in future plan implementation we expect that the importance of values and different value categories will increase strongly in land management procedures. Hence, by seeking boundary objects and emphasizing boundary work it should be possible to derive transdisciplinary concepts which can connect or relate different value systems. These should better describe and predict the effects of land-use interventions and develop improved transdisciplinary models to predict changes and development in the utilization of land or property.

\section{References}

Ali, D.A.; Deininger, K.; Goldstein, M. (2014): Environmental and gender impacts of land tenure regularization in Africa: Pilot evidence from Rwanda. In: Journal of Development Economics 110, 262-275. doi: 10.1016/j.jdeveco.2013.12.009

Appraisal Institute (2008): The appraisal of real estate. Chicago.

Aust, M.; Jacobs, R.; Pasternak, D. (2014): Enteignungsentschädigung. Berlin.

Bannister, F.; Connolly, R. (2014): ICT, public values and transformative government: A framework and programme for research. In: Government Information Quarterly 31, 1, 119-128. doi: 10.1016/j.giq.2013.06.002

BMBF - Bundesministerium für Bildung und Forschung (2008): Paths to Sustainable Land Management. Topics and Projects in the REFINA Research Programme. Berlin.

Bosse, C. (2016): Fledermäuse oder Autobahn? Warum kann es aus dem Ruder laufen? ZDF online: Planet E (Dokumentation der Sendung vom 18.09.2016).

Boyne, G.; Powell, M. (1991): Territorial justice: A review of theory and evidence. In: Political Geography Quarterly 10, 3, 263-281. doi: 10.1016/0260-9827(91)90038-V

Brenner, N.; Marcuse, P.; Mayer, M. (2012): Cities for people, not for profit: critical urban theory and the right to the city. London/New York.

Chigbu, U.E. (2012): Village renewal as an instrument of rural development: evidence from Weyarn, Germany. In: Community Development 43, 2, 209-224. doi: 10.1080/15575330.2011.575231

Cook, M.; Harrison, T.M. (2015): Using public value thinking for government IT planning and decision making: A case study. In: Information Polity 20, 2/3, 183-197. doi: 10.3233/IP-150359

de Vries, W.T. (2008): A review of the political nature of ICT in G2G integration - based on 3 cases from the geoICT domain. In: Chun, S.A.; Janssen, M.; Gil-Garcia, J.R. (eds.): Proceedings of the 9th Annual International Conference on Digital Government Research. Montreal, 124-131.

De Vries, W.T. (ed.) (2017a): Attraktiv und lukrativ? Ideelle und finanzielle Wertschätzungen Ländlicher Räume. 19. Münchner Tage für Nachhaltiges Landmanagement München = Materialiensammlung 49, Lehrstuhl für Bodenordnung und Landentwicklung, Technische Universität München.

De Vries, W.T. (2017b): Human geodesy. Shaping a new science and profession for the world of tomorrow. Presentation at the FIG Working Week Helsinki.
De Vries, W.T.; Chigbu, U.E. (2017): Responsible land management. Concept and application in a territorial rural context. In: Flächenmanagement und Bodenordnung 79, 2, 65-73.

De Vries, W.T.; Miscione, G. (2010): Relationality in Geo-Information value: Price as product of socio-technical networks. In: International Journal of Spatial Data Infrastructures Research 5, 77-95.

Drixler, E.; Friesecke, F.; Kötter, T.; Weitkamp, A.; Weiß, D. (2014): Kommunale Bodenpolitik und Baulandmodelle - Strategien für bezahlbaren Wohnraum? Eine vergleichende Analyse in deutschen Städten. Augsburg. = Schriftenreihe des DVW 76.

Dushimyiman Simbizi, M.C.D. (2016): Measuring land tenure security: a pro-poor perspective. Dissertation, University of Twente, Enschede.

Ernst, W.; Bonczek, W. (1971): Zur Reform des städtischen Bodenrechts. Hannover.

Forschungsgruppe ART (Agrar- und Regionalentwicklung Triesdorf) (2008): Effizienz staatlich geförderter Flurneuordnungsverfahren nach dem Flurbereinigungsgesetz (FlurbG). Abschlussbericht. Triesdorf.

Gerber, J.-D.; Hartmann, T.; Hengstermann, A. (eds.) (2018): Instruments of land policy. Dealing with scarcity of land. London/New York.

Hinz, S.A. (2012): Ganzheitliches Wertschöpfungsmodell der Waldflurbereinigung und deren Effizienzsteigerung. Neubiberg. = Schriftenreihe, Institut für Geodäsie, Universität der Bundeswehr München 89.

Jowsey, E. (2011): Real Estate Economics. Basingstoke.

Kalandides, A. (2011): The problem with spatial identity: revisiting the "sense of place". In: Journal of Place Management and Development 4, 1, 28-39. doi: 10.1108/17538331111117142

Kalbro, T.; Paulsson, J. (2014): Development of Swedish Legislation regulating Compensation for Compulsory Acquisition. A Law and Economics Perspective. In: European Property Law Journal 3, 3, 215-230. doi: 10.1515/eplj-2014-0010

Kernaghan, K. (2003): Integrating values into public service: The values statement as centerpiece. In: Public Administration Review 63, 6, 711-719. doi: 10.1111/1540-6210.00334

Kleiber, W. (2017): Verkehrswertermittlung von Grundstücken. Kommentar und Handbuch. Köln.

Klopp, J.M.; Petretta, D.L. (2017): The urban sustainable development goal: Indicators, complexity and the politics of measuring cities. In: Cities 63, 92-97. doi: 10.1016/j.cities.2016.12.019

Kötter, T.; Berend, L.; Drees, A.; Kropp, S.; Linke, H.J.; Lorig, A.; Reuter, F.; Thiemann, K.-H.; Voß, W.; Weitkamp, A. (2015): Land-und Immobilienmanagement - Begriffe, Handlungsfelder und Strategien. In: Zeitschrift für Geodäsie, Geoinformation und Landmanagement 140, 3, 136-146. doi: 10.12902/zfv-0064-2015

Kötter, T.; Frielinghaus, B. (2012): Städtebauliche Kalkulation. Eine Methode zur Ermittlung von Siedlungs-und Infrastrukturkosten. Vogtsburg-Oberrotweil. = DVW-Merkblatt 4-2012.

Lefebvre, H. (1996): The right to the city. In: Lefebvre, H. (ed.): Writings on cities. Selected, translated and introduced by E. Kofman and E. Lebas. Oxford, 147-159.

Magel, H. (2016): Räumliche Gerechtigkeit - ein Thema für Landentwickler und sonstige Geodäten?! In: Zeitschrift für Vermessungswesen 141, 6, 377-383.

Magel, H.; Thiel, F.; Espinoza, J. (2016): Bodenpolitik und Landmanagement: Eine internationale Perspektive. In: Freeden, W.; Rummel, R. (eds.): Handbuch der Geodäsie, Band Bodenordnung und Landmanagement. Berlin/Heidelberg, 1-33. doi: 10.1007/978-3662-46900-2_84-1

Markuszewska, I. (2014): Farmland Merging in Poland. A Success or Failure in Land Management Policy. In: Journal of Earth Science and Engineering 4, 4, 643-649. doi: 10.17265/2159581X/2014.10.007

Mattsson, H.; Mansberger, R. (2017): Land Governance/Management Systems. In: Hepperle, E.; Dixon-Gough, R.; Mansberger, R.; Paulsson, J.; Hernik, J.; Kalbro, T. (eds.): Land Ownership and 
Land Use Development: The Integration of Past, Present, and Future in Spatial Planning and Land Management Policies. Zürich, 13-24.

Miller, D. (2012): Territorial rights: concept and justification. In: Political Studies 60, 2, 252-268. doi: 10.1111/j.1467-9248.2011. 00911.x

Mitchell, D. (2003): The right to the city: Social justice and the fight for public space. New York.

Moody, R. (2010): Mapping Power. Geographical Information Systems, Agenda-Setting and Policy Design. Dissertation, Erasmus Universiteit Rotterdam.

Moore, M.H. (1994): Public value as the focus of strategy. In: Australian Journal of Public Administration 53, 3, 296-303. doi: 10.1111/j.1467-8500.1994.tb01467.x

Mooya, M.M. (2016): Real Estate Valuation Theory - A Critical Appraisal. Berlin/Heidelberg. doi: 10.1007/978-3-662-49164-5

Perin, C. (2014): Everything in its place: Social order and land use in America: Princeton.

Raymond, C.M.; Bieling, C.; Fagerholm, N.; Martin-Lopez, B.; Plieninger, T. (2016): The farmer as a landscape steward: Comparing local understandings of landscape stewardship, landscape values, and land management actions. In: Ambio 45, 2, 173-184. doi: 10.1007/s13280-015-0694-0

RICS - Royal Institution of Chartered Surveyors (2017): RICS valuation - Global standards 2017. London.

Schmitz, C.; van Meijl, H.; Kyle, P.; Nelson, G.C.; Fujimori, S.; Gurgel, A.; Havlik, P.; Heyhoe, E.; d'Croz, D.M.; Popp, A.; Sands, R.; Tabeau, A.; van der Mensbrugghe, D.; von Lampe, M.; Wise, M.; Blanc, E.; Hasegawa, T.; Kavallari, A.; Valin, H. (2014): Land-use change trajectories up to 2050: Insights from a global agro-economic model comparison. In: Agricultural Economics 45, 1, 69-84. doi: 10.1111/agec. 12090

Seele, W. (1976): Ausgleich maßnahmenbedingter Bodenwerterhöhungen. Bonn. = Schriftenreihe Städtebauliche Forschung des Bundesministers für Raumordnung, Bauwesen und Städtebau 03.047 .

Smith, A. (2005) [1776]: An Inquiry into the nature and causes of the wealth of nations. London.

Squires, G.; Heurkens, E. (2016): Methods and models for international comparative approaches to real estate development. In: Land Use Policy 50, 573-581. doi: 10.1016/j.landusepol.2015. 10.005

Star, S.L.; Griesemer, J.R. (1989): Institutional Ecology, 'Translations' and Boundary Objects: Amateurs and Professionals in Berkeley's Museum of Vertebrate Zoology, 1907-39. In: Social Studies of Science 19, 3, 387-420.

Strezov, V.; Evans, A.; Evans, T.J. (2017): Assessment of the Economic, Social and Environmental Dimensions of the Indicators for Sustainable Development. In: Sustainable Development 25, 3, 242-253. doi: doi.org/10.1002/sd.1649

Teshome, A.; de Graaff, J.; Ritsema, C.; Kassie, M. (2016): Farmers' perceptions about the influence of land quality, land fragmentation and tenure systems on sustainable land management in the North Western Ethiopian Highlands. In: Land Degradation and Development 27, 4, 884-898. doi: 10.1002/ldr.2298

Veldkamp, T.; Polman, N.; Reinhard, S.; Slingerland, M. (2011): From Scaling to Governance of the Land System: Bridging Ecological and Economic Perspectives. In. Ecology and Society 16, 1, 1.

Voß, W. (2010): Appropriate compensation in terms of compulsory purchase in Germany. In: The Polish Real Estate Scientific Society (ed.): Some aspects of compulsory purchase of land for public purposes. Olsztyn, 55-69.

Voß, W. (2014): Is Affordable Housing Still Viable in Metropolitan Urban Development? Presentation at the FIG-Congress 2014 Kuala Lumpur.

Voß, W.; Dransfeld, E.; Dieterich, H. (1994): Die Bodenpreisbildung. Ein Blick auf neue Instrumente und einige Nachbarländer. In: Grundstücksmarkt und Grundstückswert 5, 4, 200-210. 